\title{
KARAKTER MORFOLOGI DAN HUBUNGAN KEKERABATAN GALUR-GALUR KACANG BOGOR (Vigna subterranea L. Verdc.) ASAL LANRAS SUKABUMI
}

\author{
Morphological Characteristics and Kinship Relationship of Bambara Groundnut \\ (Vigna subterranea L. Verdc.) Lines of Sukabumi Landrace \\ Wiellda Novia Sasnia ${ }^{1}$, Yuliawati ${ }^{2 *}$, Arifah Rahayu ${ }^{2}$, Setyono $^{2}$ \\ ${ }^{1}$ Program Studi Agroteknologi, Fakultas Pertania, Universitas Djuanda \\ ${ }^{2}$ Staf Pengajar Program Studi Agroteknologi, Fakultas Pertania, Universitas Djuanda \\ Jalan Tol Ciawi, No. 1 Kotak Pos 35 Ciawi-Bogor, 16720 \\ "Email korespondensi: yuliawati@unida.ac.id
}

Diterima 31 Maret 2021/Disetujui 27 April 2021

\begin{abstract}
ABSTRAK
Kegiatan pemuliaan tanaman kacang bogor telah dimulai dengan eksplorasi, seleksi dan evaluasi lanras-lanras lokal Indonesia, salah satunya lanras lokal asal Sukabumi. Seleksi kacang bogor asal lanras Sukabumi telah dilakukan menggunakan teknik seleksi galur murni. Galur-galur tersebut masih perlu dievaluasi karakter morfologi dan hubungan kekerabatannya agar program seleksi yang dilakukan berjalan efektif. Tujuan dari penelitian ini adalah untuk mengidentifikasi perbedaan atau persamaan karakter morfologi antar galur-galur kacang bogor asal lanras Sukabumi dan mengidentifikasi silsilah galur yang memiliki potensi hasil tinggi melalui analisis kekerabatan. Penelitian dilaksanakan di kebun percobaan SEAMEO BIOTROP Tajur, Bogor (280 m dpl) pada bulan Februari-Juni 2018. Bahan tanam yang digunakan adalah 30 galur kacang bogor hasil seleksi galur murni asal lanras Sukabumi dan lanras Sukabumi yang tidak diseleksi sebagai kontrol. Rancangan penelitian yang digunakan adalah Rancangan Acak Kelompok (RAK) dengan 3 ulangan. Hasil penelitian ini menunjukkan bahwa galur-galur kacang bogor asal lanras Sukabumi memiliki perbedaan morfologi pada semua karakter, kecuali pada karakter warna daun. Galur-galur tersebut memiliki perbedaan pada tipe tumbuh, bentuk daun, bulu pada batang, pigmen pada bunga, bentuk polong, warna polong, tekstur polong, warna biji, dan bentuk biji. Berdasarkan hasil analisis kekerabatan, nilai kemiripan genetik antar galur-galur kacang bogor asal lanras Sukabumi tergolong sangat tinggi yang disebabkan oleh tingkat keragaman yang sempit.
\end{abstract}

Kata kunci: daya hasil, pemuliaan tanaman, seleksi

\section{ABSTRACT}

The plant breeding program of Bambara groundnut has started with the exploration, selection, and evaluation activity of Indonesian local landraces, including the Sukabumi landrace. Bambara groundnut selection activities of Sukabumi landrace have been carried out using pure line selection techniques. The lines obtained from the pure line selection still need to be evaluated for their morphological characters and kinship, so that the selected program is carried out effectively. This study aimed to identify differences or similarities in morphological characters between Bambara groundnut lines of Sukabumi landrace and identify lineages that have high yield potential through kinship analysis. This experiment was carried out in the experimental field of SEAMEO BIOTROP, Tajur, Bogor ( $\pm 280 \mathrm{~m}$ asl) on February-June 2018. Plant materials used in this research were 30 Bambara groundnut lines derived from pure line selection of Sukabumi landrace and unselected Sukabumi landrace was used as control. The experiment was arranged in a Randomized Complete Block Design $(R C B D)$ with 3 replications. The result showed that Bambara groundnut lines of Sukabumi landrace have morphological differences in all characters, except for the leaf color character. These lines have differences in growth type, leaf shape, hair on stems, flower pigment, pod shape, pod color, pod texture, seed color, and seed shape. The Kinship analysis result showed that the value of genetic similarity among Bambara groundnut lines of Sukabumi landrace was very high due to a narrow level of diversity.

Keywords: plant breeding, selection, yield 


\section{PENDAHULUAN}

Kacang bogor (Vigna subterranea L. Verdc.) atau yang dikenal juga dengan nama bambara groundnut merupakan jenis tanaman legum asal Afrika yang sudah lama beradaptasi dengan baik di berbagai wilayah Indonesia. Kacang bogor terbukti memiliki kandungan nutrisi yang tinggi berdasarkan beberapa hasil pengujian. Menurut Mazahib et al. (2013), dalam 100 g kacang bogor terkandung 19,28-20,60\% protein, 56,25-61,01\% karbohidrat, dan 6,60-8,49\% lemak, selain itu terkandung juga 184,0 mg kalsium, 4,40 mg zat besi, 45,7 mg kalium, dan 9,14 mg natrium. Kandungan nutrisi tersebut menyebabkan kacang bogor tergolong salah satu sumber pangan lengkap dan potensial untuk dijadikan sumber pangan alternatif. Kacang bogor juga memiliki keunggulan lain selain dari segi nutrisi, yaitu dapat ditanam pada tanah dengan kandungan unsur hara rendah dan tahan terhadap cekaman kekeringan (Azam-Ali et al. 2001). Di Afrika, kacang bogor ditanam oleh petani-petani kecil pada tanah kurang subur dan iklim panas yang tanaman kacang-kacangan lain sulit untuk tumbuh (Brough et al. 1993).

Produktivitas kacang bogor masih tergolong rendah dan belum tersedia varietas nasionalnya sampai saat ini. Petani-petani di Indonesia masih menggunakan lanras-lanras lokal yang genotipenya masih tercampur, sehingga produksinya sangat rendah. Menurut Redjeki (2007), rata-rata produksi polong kering kacang bogor yang ditanam di Indonesia masih di bawah $4 \mathrm{t} \mathrm{ha}^{-1}$. Evaluasi daya hasil yang dilakukan Berchie et al. (2010) terhadap tiga lanras kacang bogor menunjukkan rata-rata produksi 1,3-2,4 $\mathrm{t} \mathrm{ha}^{-1}$ untuk polong kering. Kondisi tersebut menyebabkan upaya perbaikan produktivitas atau daya hasil kacang bogor melalui program pemuliaan tanaman sangat penting untuk dilakukan.
Kegitan pemuliaan tanaman kacang bogor di Indonesia telah dimulai sejak tahun 2012 melalui kegiatan eksplorasi, seleksi dan evaluasi lanras-lanras lokal, salah satunya lanras lokal asal Sukabumi. Seleksi kacang bogor asal lanras Sukabumi telah dilakukan menggunakan teknik seleksi galur murni. Menurut Syukur et al. (2012), seleksi galur murni merupakan teknik seleksi tanaman tunggal dari populasi homozigot heterogen yang didasari oleh pernyataan bahwa keragaman dalam populasi heterozigot disebabkan keragaman genetik dan lingkungan, sementara keragaman pada populasi galur murni hanya disebabkan oleh keragaman lingkungan. Galur-galur kacang bogor hasil seleksi galur murni tersebut masih perlu dievaluasi agar dapat dilepas sebagai varietas unggul berdaya hasil tinggi.

Galur-galur kacang bogor yang digunakan pada penelitian ini adalah asal Sukabumi hasil seleksi galur murni. Galurgalur tersebut dievaluasi karakter morfologi dan hubungan kekerabatannya agar program seleksi yang dilakukan berjalan efektif. Evaluasi karakter morfologi dilakukan untuk mengidentifikasi perbedaan atau persamaan karakter morfologi antar galurgalur kacang bogor, sementara analisis kekerabatan dilakukan untuk mengidentifikasi silsilah genotip yang memiliki potensi hasil tinggi.

\section{MATERI DAN METODE}

Penelitian ini dilaksanakan pada bulan Februari-Juni 2018 di kebun percobaan SEAMEO BIOTROP Tajur, dengan ketinggian tempat $\pm 280 \mathrm{~m} \mathrm{dpl}$. Rancangan penelitian yang digunakan adalah Rancangan Acak Kelompok (RAK) faktor tunggal dengan 3 kelompok. Faktor yang diuji adalah 30 galur kacang bogor asal lanras Sukabumi hasil seleksi galur murni dan satu lanras kacang bogor asal Sukabumi yang tidak diseleksi sebagai pembanding. Setiap galur kacang bogor 
ditanam dalam baris dan dibuat menjadi 3 kelompok. Satu satuan percobaan terdiri atas dua baris tanaman yang masingmasing barisnya terdiri atas 10 tanaman, sehingga satu satuan percobaan terdiri dari 20 tanaman.

Alat yang digunakan pada penelitian ini adalah alat budidaya, label, kantong plastik bening, kantong jaring, seedbox, kamera digital, thermohygrometer dan timbangan analitik. Bahan tanaman yang digunakan adalah galur kacang bogor asal lanras Sukabumi, sementara bahan lainnya adalah pupuk kandang ayam, pestisida karbofuran, pupuk NPK (15-15-15), pestisida, dan fungisida berbahan aktif mankozeb $80 \%$.

Penelitian diawali dengan pembersihan lahan dari gulma dan sisasisa tanaman. Lahan diolah dua minggu sebelum penanaman dengan menggunakan alat pengolahan tanah tradisional seperti cangkul dan garu. Setelah tanahnya gembur, lahan dibuat menjadi tiga petak besar berukuran $4 \mathrm{~m}$ x 37,2 $\mathrm{m}$ dengan jarak antar petak $\pm 1 \mathrm{~m}$. Pemberian pupuk kandang dengan dosis $10 \mathrm{t} \mathrm{ha}^{-1}$ dilakukan satu minggu sebelum penanaman. Masingmasing benih per galur ditanam dalam dua baris, tiap baris terdiri atas 10 tanaman dengan jarak tanam $60 \mathrm{~cm} \times 40 \mathrm{~cm}$. Penanaman benih kacang bogor dilakukan bersama aplikasi pupuk NPK (15:15:15) dengan dosis $200 \mathrm{~kg} \mathrm{ha}^{-1}$ dan pemberian insektisida berbahan aktif karbofuran dengan dosis $20 \mathrm{~kg} \mathrm{ha} \mathrm{ha}^{-1}$. Penyulaman dilakukan pada saat tanaman berumur 14 hari setelah tanam (HST). Pembumbunan dilaksanakan pada 32, 55 dan 80 HST, sementara pengendalian gulma dilakukan setiap dua minggu sekali. Penyemprotan insektisida berbahan aktif deltametrin $25 \mathrm{~g}$ $\mathrm{L}^{-1}$ dilakukan pada 30, 46, 61 dan 73 HST. Panen dilaksanakan secara serentak pada umur 112 HST dan pengeringan benih di bawah sinar matahari dilakukan selama \pm 14 hari,

Pengamatan dilakukan menggunakan metode deskriptif yang mengacu pada Descriptors for Bambara
Groundnut (IPGRI 2000). Data yang telah terstandarisasi diolah menggunakan program minitab dengan metode analisis gerombol (cluster) untuk mengetahui tingkat kekerabatan antar galur kacang bogor. Analisis gerombol merupakan suatu teknik analisis multivariat yang bertujuan untuk mengelompokkan data observasi ataupun variabel-variabel dalam cluster, sehingga masing-masing bersifat homogen sesuai dengan faktor yang digunakan untuk penggerombolan (Gudono 2011). Analisis gerombol tersebut menghasilkan data berupa dendogram.

\section{HASIL DAN PEMBAHASAN}

\section{Karakter Morfologi}

Karakter kualitatif adalah karakter yang dikendalikan oleh gen satu atau dua gen dan tidak atau sedikit sekali dipengaruhi oleh lingkungan (Syukur et al. 2012). Karakter kualitatif dapat dibedakan berdasarkan kelas atau jenis dan digunakan sebagai penentu karakter morfologi.

Berdasarkan hasil pengamatan, galur-galur kacang bogor asal lanras Sukabumi memiliki tipe pertumbuhan berbeda, yaitu tegak serta tegak menyebar. Galur R59.30, A51.9, A41.4, A97.4, A43.5, A90.8, dan pembanding memiliki tipe tumbuh tegak dan menyebar, sementara 24 galur lain memiliki tipe tumbuh tegak (Tabel 1). Hal ini sesuai dengan pernyataan Kuswanto (2012), bahwa pertumbuhan kacang bogor asal Jawa Barat umumnya bertipe tegak, tegak dan menyebar, dan menyebar. Tipe tumbuh kacang bogor ditentukan berdasarkan rasio antara panjang petiole dan internode. Berdasarkan rasio tersebut, Gao et al. (2020) mengelompokan lanraslanras kacang bogor asal Afrika dan Asia Tenggara menjadi tipe tumbuh bunch dengan rasio 9,65-13,36 dan semi-bunch dengan rasio 5,55-8,49.

Hasil pengamatan pada warna daun menunjukkan bahwa seluruh galur uji memiliki daun berwarna hijau, sementara bentuk daunnya dibedakan atas oval, bulat 
dan lanset (Gambar 1). Bentuk daun oval dimiliki oleh galur R59.30, A101.10, A85.5, A41.4, A97.4, A13.9, A43.5, A55.8, R16.5, A73.5, A122.5, A41.4, R9.11, A28.10, A103.5, A96.10, A63.10, A126.11, R59.31, A47.7 dan kontrol. Bentuk daun bulat dimiliki oleh galur A48.5 dan A56.10. Bentuk daun lanset dimiliki oleh galur A22.70, A45.9, A51.9, A36.6, A13.9, A37.2, A90.8, dan A22.71 (Tabel 1). Hasil yang sama diperoleh Wicaksana et al. (2013) yang menyatakan bahwa daun kacang bogor asal Sukabumi $1,33 \%$ berbentuk bulat, $57,33 \%$ berbentuk lanset dan $41,33 \%$ berbentuk elip.
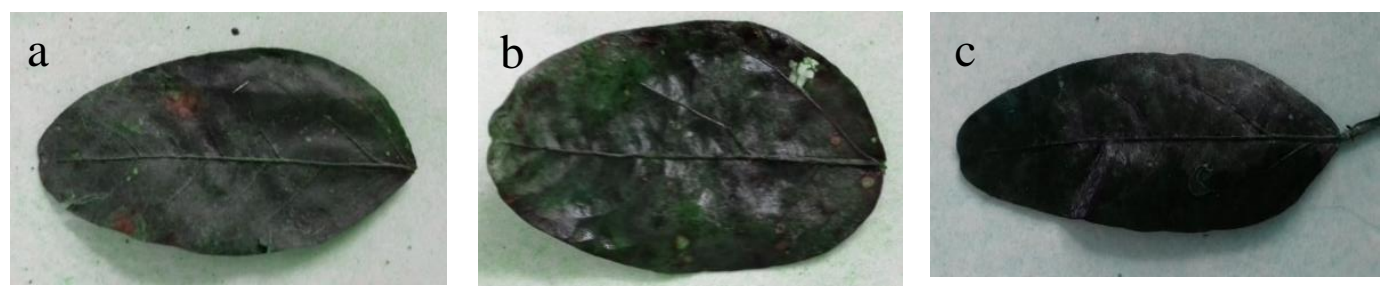

Gambar 1. Bentuk daun (a) oval, (b) bulat, (c) lanset

Diantara galur kacang bogor lanras Sukabumi terdapat tiga galur tanaman yang sama sekali tidak memiliki bulu pada batangnya, yaitu galur A22.70, A45.9, dan A51.9 (Tabel 1). Bulu pada batang tanaman umumnya berfungsi untuk

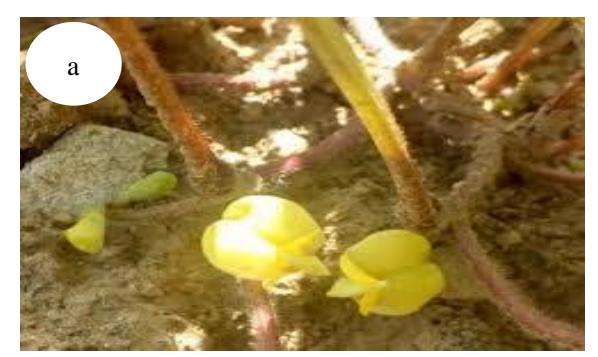

mengurangi penguapan dan gangguan mekanik. Kacang bogor memiliki warna mahkota bunga kuning keputihan dan beberapa mahkota bunganya memiliki pigmen ungu pada bagian pangkal sayap bunga (Gambar 2).

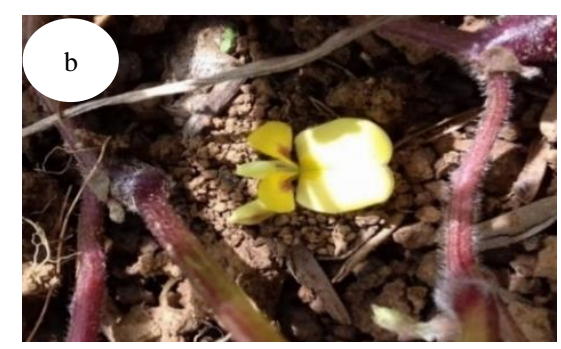

Gambar 2. Bunga kacang bogor (a) tanpa pigmen antosianin (b) memiliki pigmen antosianin

Hasil pengamatan pigmen pada mahkota bunga menunjukkan bahwa galur R59.3，A101.10，A22.7，A45.9，A51.9, A13.9, A48.5, A97.4, A13.9, A43.5, A37.2, A55.8, A90.8, A36.6, R16.5, A73.5, A22.7, A122.5, A41.4, R9.11, A28.10, A103.5, A96.10, A63.10, dan A126.11 memiliki pigmen berwarna ungu, sedangkan galur lainnya tidak berpigmen (Tabel 1). Warna ungu tersebut disebabkan oleh adanya pigmen antosianin. Selain dipengaruhi faktor genetik, keberadaan pigmen antosianin juga dipengaruhi oleh lingkungan karena semakin rendah $\mathrm{pH}$ akan diikuti dengan peningkatan kemampuan tanaman dalam menghasilkan pigmen antosianin (Wulaningrum et al. 2013).

Galur-galur kacang bogor asal lanras sukabumi memiliki dua bentuk polong, yaitu bulat dan buat mengarah pada salah satu titik (Gambar 3). Galur R59.30, A101.10, A85.5, A51.9, A37.2, A36.6, R16.5 dan A22.71 memiliki bentuk polong bulat dengan satu titik di salah satu bagian ujungnya, sedangkan galur uji lainnya memiliki bentuk polong bulat (Tabel 1). Hasil pengamatan Ntundu et al. (2006) terhadap lanras-lanras kacang bogor asal Tanzania memberikan hasil tidak jauh berbeda, dimana kacang bogor memiliki bentuk bulat dan bulat dengan titik pada salah satu ujung. 
Tabel 1. Karakter morfologi galur-galur kacang bogor asal lanras Sukabumi hasil seleksi galur murni

\begin{tabular}{|c|c|c|c|c|c|c|c|c|c|c|}
\hline Galur & Tipe tumbuh & $\begin{array}{c}\text { Bentuk } \\
\text { daun }\end{array}$ & $\begin{array}{c}\text { Warna } \\
\text { daun }\end{array}$ & $\begin{array}{c}\text { Bulu } \\
\text { batang }\end{array}$ & $\begin{array}{c}\text { Pigmen } \\
\text { bunga }\end{array}$ & Bentuk polong & Warna polong & $\begin{array}{l}\text { Tekstur } \\
\text { polong }\end{array}$ & $\begin{array}{l}\text { Bentuk } \\
\text { biji }\end{array}$ & Warna biji \\
\hline R59.30 & Tegak dan menyebar & Oval & Hijau & Sedikit & Ada & bulat dengan satu titik & Coklat & licin & Bulat & hitam \\
\hline A101.10 & Tegak & Oval & Hijau & Sedikit & Ada & bulat dengan satu titik & Coklat & licin & Oval & hitam \\
\hline A85.5 & Tegak & Oval & Hijau & Sedikit & tidak ada & bulat dengan satu titik & kuning kecoklatan & licin & Oval & hitam \\
\hline A22.70 & Tegak & Lanset & Hijau & tidak ada & Ada & Bulat & kuning kecoklatan & licin & Oval & coklat gelap \\
\hline A45.9 & Tegak & Lanset & Hijau & tidak ada & Ada & Bulat & kuning kecoklatan & licin & Oval & coklat gelap \\
\hline A51.9 & Tegak dan menyebar & Lanset & Hijau & tidak ada & Ada & bulat dengan satu titik & kuning kecoklatan & licin & Oval & hitam \\
\hline A13.9 & Tegak & Lanset & Hijau & Sedikit & Ada & Bulat & kuning kecoklatan & licin & Bulat & coklat gelap \\
\hline A48.5 & Tegak & Bulat & Hijau & Sedikit & Ada & Bulat & kuning kecoklatan & licin & Bulat & hitam \\
\hline A56.10 & Tegak & Bulat & Hijau & Sedikit & tidak ada & Bulat & Coklat & licin & Oval & coklat gelap \\
\hline A41.4 & Tegak dan menyebar & Oval & Hijau & Sedikit & tidak ada & Bulat & kuning kecoklatan & licin & Oval & coklat gelap \\
\hline A97.4 & Tegak dan menyebar & Oval & Hijau & Sedikit & ada & Bulat & Coklat & berkerut & Oval & coklat gelap \\
\hline A13.9 & Tegak & Oval & Hijau & Sedikit & ada & Bulat & kuning kecoklatan & licin & Bulat & coklat gelap \\
\hline A43.5 & Tegak dan menyebar & Oval & Hijau & Sedikit & ada & Bulat & kuning kecoklatan & licin & Oval & hitam \\
\hline A 37.2 & Tegak & Lanset & Hijau & Sedikit & ada & bulat dengan satu titik & kuning kecoklatan & licin & Oval & hitam \\
\hline A55.8 & Tegak & Oval & Hijau & Sedikit & ada & Bulat & kuning kecoklatan & licin & Oval & hitam \\
\hline A90.8 & Tegak dan menyebar & Lanset & Hijau & Sedikit & ada & Bulat & kuning kecoklatan & licin & Oval & hitam \\
\hline A36.6 & Tegak & Lanset & Hijau & Sedikit & ada & bulat dengan satu titik & Coklat & licin & Bulat & hitam \\
\hline R16.5 & Tegak & Oval & Hijau & Sedikit & ada & bulat dengan satu titik & kuning kecoklatan & licin & Oval & coklat gelap \\
\hline A73.5 & Tegak & Oval & Hijau & Sedikit & ada & Bulat & Coklat & licin & Oval & coklat gelap \\
\hline A22.71 & Tegak & Lanset & Hijau & Sedikit & ada & bulat dengan satu titik & kuning kecoklatan & licin & Oval & hitam \\
\hline A122.5 & Tegak & Oval & Hijau & Sedikit & ada & Bulat & kuning kecoklatan & licin & Oval & hitam \\
\hline A41.4 & Tegak & Oval & Hijau & Sedikit & ada & Bulat & kuning kecoklatan & licin & Oval & hitam \\
\hline R9.11 & Tegak & Oval & Hijau & Sedikit & ada & Bulat & kuning kecoklatan & licin & Oval & hitam \\
\hline A28.10 & Tegak & Oval & Hijau & Sedikit & ada & Bulat & Coklat & licin & Bulat & coklat gelap \\
\hline A103.5 & Tegak & Oval & Hijau & Sedikit & ada & Bulat & kuning kecoklatan & licin & Bulat & hitam \\
\hline A96.10 & Tegak & Oval & Hijau & Sedikit & ada & Bulat & Coklat & licin & Bulat & hitam \\
\hline A63.10 & Tegak & Oval & Hijau & Sedikit & ada & Bulat & Coklat & licin & Oval & hitam \\
\hline A126.11 & Tegak & Oval & Hijau & Sedikit & ada & Bulat & kuning kecoklatan & berkerut & Bulat & coklat gelap \\
\hline R59.31 & Tegak & Oval & Hijau & Sedikit & tidak ada & Bulat & kuning kecoklatan & licin & Oval & hitam \\
\hline A 47.7 & Tegak & Oval & Hijau & Sedikit & tidak ada & Bulat & kuning kecoklatan & licin & Oval & coklat gelap \\
\hline Pembanding & Tegak dan menyebar & Oval & Hijau & Sedikit & tidak ada & Bulat & Coklat & licin & Oval & coklat gelap \\
\hline
\end{tabular}


Pembanding, R59.3, A101.10, A56.10, A97.4, A36.6, A73.5, A28.10, A96.10, dan A63.10 memiliki polong berwarna coklat, sedangkan galur lainnya memiliki warna polong kuning kecoklatan. Perbedaan warna polong tersebut selain disebabkan oleh faktor genetik, diduga disebabkan juga oleh tingkat kemasakan yang berbeda. Menurut Manggung et al.
(2016), polong kacang bogor berwarna kuning kecoklatan dengan bintik coklat pada tingkat kemasakan 112 HST, sedangkan polong berwarna kecoklatan dengan guratan coklat menjelang masak pada 128 HST. Galur uji yang memiliki tekstur polong berkerut yaitu galur A97.4 dan A126.11, sedangkan galur uji lainnya bertekstur licin.
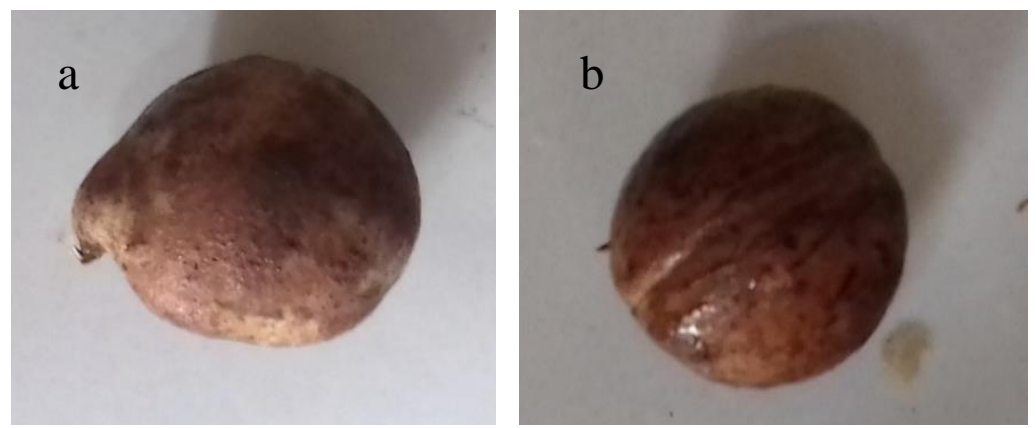

Gambar 3. Bentuk polong (a) bulat dengan satu titik (b) bulat

Galur A101.10, A85.5, A22.70, A45.9, A51.9, A56.10, A41.4, A97.4, A 43.5, A37.2, A55.8, A90.8, R16.5, A73.5, A22.71, A122.5, A41.4, R9.11, A63.10, R59.31 dan A47.7 memiliki bentuk biji oval sama seperti pembanding, sedangkan galur R59.30, A13.9, A48.5, A13.9, A36.6, A28.10, A103.5, A96.10 dan A126.11 bijinya berbentuk bulat (Tabel 1). Warna kulit biji atau testa kacang bogor lanras Sukabumi dapat

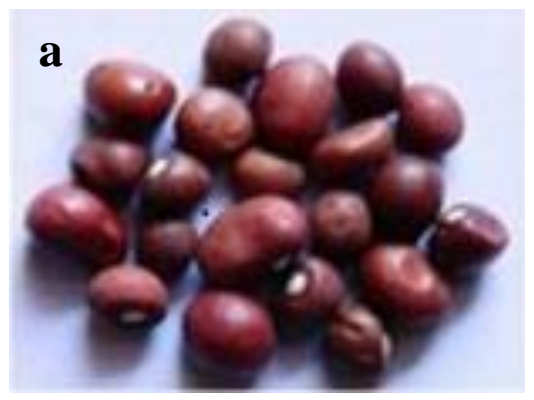

Gambar 4. Biji kacang bogor (a) testa coklat (b) testa hitam

Genotipe-genotipe terseleksi asal lanras-lanras lokal Jawa Barat hasil pengujian Fias et al. (2015), menunjukan bentuk biji sama tetapi warna biji yang lebih beragam. Berdasarkan penelitian

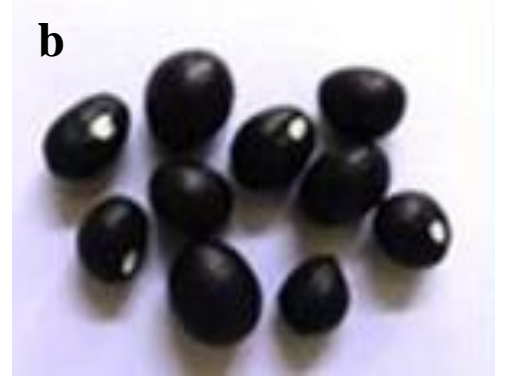

dibedakan atas coklat gelap dan hitam (Gambar 4). Galur A22.70, A45.9, A13.9, A56.10, A41.4, A97.4, A13.9, R16.5, A73.5, A28.10, A126.11, A47.7 dan galur kontrol memiliki warna biji coklat gelap. Galur R59.30, A101.10, A85.5, A51.9, A48.5, A43.5, A37.2, A55.8, A90.8, A36.6, A22.71, A122.5, A41.4, R9.11, A103.5, A96.10, A63.10 dan R59.31 memiliki warna biji hitam (Tabel 1).

tersebut, kacang bogor memiliki bentuk biji bulat dan oval, sementara warna bijinya ungu tua, coklat muda, merah tua, merah terang, dan coklat tua. Menurut Illahi (2015), keragaman genetik kulit biji 
kacang bogor asal Sukabumi lebih rendah dibandingkan kacang bogor asal Sumedang. Kacang bogor asal Sukabumi memiliki warna kulit biji coklat dan hitam, sedangkan kacang bogor asal Sumedang memiliki kulit biji warna krem, coklat, hitam keunguan dan hitam.

\section{Hubungan Kekerabatan}

Analisis gerombol merupakan analisis multivariat yang bertujuan untuk mengelompokkan objek dari data yang diteliti berdasarkan kesamaan karakteristik yang dimilikinya. Berdasarkan hasil analisis diperoleh nilai hubungan kekerabatan yang dapat dilihat pada Tabel 3. Hubungan kekerabatan galur-galur pada penelitian ini diuji berdasarkan karakter kuantitatif dan kualitatif. Karakter kuantitatif yang dimasukkan hanya yang memiliki pengaruh genotipe nyata yaitu peubah lebar kanopi dan jumlah polong cipo. Karakter kualitatif yang digunakan untuk analisis hubungan kekerabatan adalah tipe tumbuh, warna daun, bentuk daun, bulu pada batang, pigmen pada bunga, bentuk polong, warna polong, tekstur polong, bentuk biji, dan warna biji. Karakter kualitatif adalah sifat yang dapat dibedakan secara diskrit tidak tumpang tindih karena dikendalikan oleh gen tunggal, sehingga mudah dikelompokkan (Austi 2014).

Tabel 2. Nilai similaritas hubungan kekerabatan galur-galur kacang bogor

\begin{tabular}{llll}
\hline No & \multicolumn{1}{c}{ Hubungan Kekerabatan } & Nilai Similaritas \\
\hline 1 & A97.4 & Check & 100 \\
2 & A13.90 & A47.7 & 100 \\
3 & A37.2 & A22.71 & 100 \\
4 & A 55.5 & A37.2 & 100 \\
5 & A122.5 & R59.31 & 100 \\
6 & A55.8 & A122.5 & 100 \\
7 & A13.91 & A126.11 & 100 \\
8 & A13.90 & A73.5 & 94,405 \\
9 & A13.90 & A51.9 & 94,405 \\
10 & A45.9 & A41.40 & 94,405 \\
11 & A55.8 & A63.10 & 94,405 \\
12 & A13.91 & A28.10 & 94,006 \\
13 & A103.5 & A96.10 & 93,649 \\
14 & A101.10 & A85.5 & 93,006 \\
15 & A55.8 & A41.41 & 93,006 \\
16 & A13.90 & R16.5 & 92,54 \\
17 & A43.5 & A55.8 & 92,167 \\
18 & A45.9 & A90.8 & 91,893 \\
19 & A22.70 & A45.9 & 89,884 \\
20 & A13.90 & A43.5 & 89,276 \\
21 & A56.10 & A97.4 & 88,81 \\
22 & R9.11 & A103.5 & 87,816 \\
23 & A48.5 & A13.91 & 86,153 \\
24 & A22.70 & A13.90 & 85,832 \\
25 & A22.70 & A56.10 & 84,92 \\
26 & A101.10 & A22.70 & 82,41 \\
27 & A36.6 & R9.11 & 80,237 \\
28 & A101.10 & A48.5 & 79,363 \\
29 & R59.30 & A101.10 & 77,702 \\
30 & R59.30 & A36.6 & 71,709 \\
\hline
\end{tabular}


Berdasarkan data nilai similaritas pada Tabel 2, maka diperoleh dendogram pengelompokan berdasarkan kesamaan karakteristik yang terdapat di antara galurgalur uji kacang bogor asal lanras Sukabumi yang dapat dilihat pada Gambar 5. Hasil dendogram menunjukkan bahwa galur dengan hubungan kekerabatan kacang bogor lanras Sukabumi pada tingkat similaritas $71 \%$ terbagi menjadi dua kelompok utama. Kelompok pertama terdiri dari galur R59.3, A101.10, A85.5, A37.2, A22.71, A51.9, A22.70, A45.9, A41.4, A90.8, A13.9, A47.7, A73.5, R16.5, A43.5, A55.8, A122.5, R59.31, A63.10, A41.41, A56.10, A97.4, galur kontrol, A48.5, A13.91, A126.11, dan A28.10. Kelompok kedua terdiri dari galur A36.6, R9.11, A103.5, dan A96.10. Kelompok pertama dan kedua terpisah karena adanya perbedaan pada karakter bulu pada batang dan pigmen pada bunga.

Pada tingkat similaritas $80 \%$, kelompok pertama terbagi menjadi tiga sub kelompok. Sub kelompok pertama terdiri atas galur R59.3 saja. Sub kelompok kedua terdiri atas galur A101.10, A85.5, A37.2, A22.71, A51.9, A22.70, A45.9, A41.4, A90.8, A13.9, A47.7, A73.5, R16.5, A43.5, A55.8, A122.5, R59.31, A63.10, A41.41, A56.10, A97.4 dan galur kontrol. Sub kelompok ketiga terdiri atas galur A48.5, A13.91, A126.11, dan A28.10. Kelompok kedua terbagi menjadi dua sub kelompok. Sub kelompok pertama terdiri atas galur A36.5 saja, dan sub kelompok kedua terdiri atas galur R9.11, A103.5, dan A96.10. Ketiga kelompok ini terpisah karena adanya perbedaan pada karakter bentuk daun.

Hubungan kekerabatan antara lanras bogor kacang Sukabumi mencapai nilai similaritas $100 \%$. Galur yang mencapai nilai similaritas $100 \%$ tersebut terdiri atas 5 kelompok. Kelompok pertama galur A85.5, A37.2, dan A22.71, kelompok kedua galur A13.9 dan A47.7, kelompok ketiga galur A55.8, A122.5, dan R59.31, kelompok keempat A97.4 dan kontrol, serta kelompok kelima galur A13.91 dan A126.11.

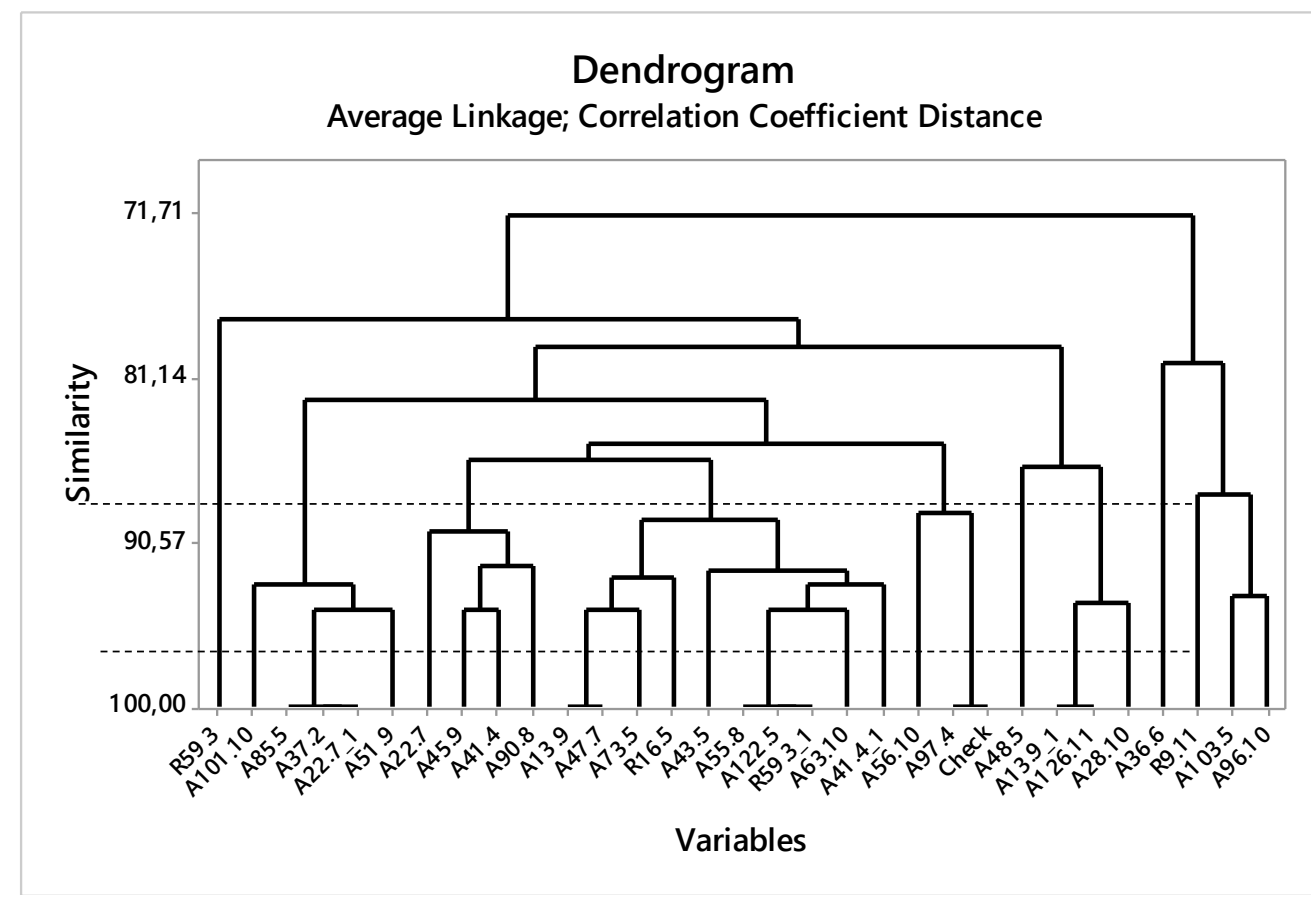

Gambar 5. Dendogram hubungan kekerabatan kacang bogor lanras Sukabumi

Berdasarkan hasil hubungan kekerabatan yang didapatkan, dengan nilai kemiripan genetik yang tinggi maka dapat dikatakan bahwa galur-galur kacang bogor 
lanras Sukabumi memiliki tingkat keragaman yang sempit. Kesamaan sifat pada kacang bogor lokal dikarenakan memiliki kekerabatan yang dekat atau karena perubahan sifat-sifat fenotipe yang dipengaruhi oleh keadaan lingkungan (Austi et al 2014). Selain untuk menduga hubungan kekerabatan, nilai kemiripan melalui dendogram dapat digunakan untuk melihat seberapa sempit atau luas nilai keragaman.

Kacang bogor merupakan tanaman yang menyerbuk sendiri dan menghasilkan keturunan yang homozigot, sehingga memiliki keragaman yang sempit. Hal tersebut disebabkan serbuk sari dan putik terdapat pada satu bunga dan terjadi penyerbukan sendiri. Walaupun demikian, keragaman penampilan tanaman akibat perbedaan sifat genetik kemungkinan tetap terjadi, sekalipun bahan tanaman yang digunakan sama. Namun, susunan genetik yang berbeda tidak selalu seluruhnya

\section{DAFTAR PUSTAKA}

Austi IR, Damanhuri, dan Kuswanto. 2014. Keragaman dan kekerabatan pada proses penggaluran kacang bogor (Vigna subterranea L.) jenis lokal. Jurnal Produksi Tanaman. 2(1):73-79.

Azam-Ali SN, Sesay A, Karikari KS, Massawe FJ, Aguilar-Manjarrez J, Bannayan M, Hampson KJ. 2001. Assessing the potential of an underutilized crop-a case study using bambara groundnut. Exp Agric. 37(4):33-72.

Berchie JN, Sarkodie-Addo H, AduDapaah A, Agyemang A, Addy S, Asare E, Donkor J. 2010. Yield evaluation of three early maturing bambara groundnut (Vigna subterranea L. Verdc.) landraces at the CSIR-Crops Research Institute, Fumensua-Kumasi, Ghana. J Agron. 9(4):175-179.

Brough SH, Taylo AJ, Azam-Ali SN. 1993. The potential of bambara diekspresikan, sehingga hanya mengakibatkan sedikit perubahan penampilan pada tanaman terutama tanaman-tanaman yang menyerbuk sendiri (Malau 2005).

\section{KESIMPULAN}

Galur-galur kacang bogor asal lanras Sukabumi memiliki perbedaan morfologi pada semua karakter, kecuali pada karakter warna daun. Galur-galur tersebut memiliki perbedaan pada tipe tumbuh, bentuk daun, bulu pada batang, pigmen pada bunga, bentuk polong, warna polong, tekstur polong, warna biji, dan bentuk biji. Berdasarkan hasil analisis kekerabatan, nilai kemiripan genetik antar galur-galur kacang bogor asal lanras Sukabumi tergolong sangat tinggi yang disebabkan oleh tingkat keragaman yang sempit.

groundnut (Vigna subterranea) in vegetable milk production and basic protein functionality systems. Food Chem. 47:277-283.

Fias NAN, Purnamaningsih SL, Kuswanto. 2015. Morphological and agronomical characters on 18 selected genotypes of bambara groundnut (Vigna Subterranea L. Verdc.). J Prod Tan. 3(2):157-163.

Gao X, Bamba ASA, Kundy AC, Mateva KI, Chai HH, Ho WK, Musa M, Mayes S, Massawe F. 2020. Variation of phenotypic traits in twelve bambara groundnut (Vigna subterranea (L.) Verdc.) genotypes and two F2 bi-parental segregating populations. Agronomy. 10(10):1-13.

Gudono. 2011. Analisis Data Multivariat Edisi Pertama. Yogyakarta: BPFE.

Illahi Z. 2015. Keragaman genetik kacang bogor (Vigna subterranea L. Verdc.) berdasarkan marka SSR (Simple Sequence Repeat). [Tesis]. Bogor: Fakultas Pertanian-Institut Pertanian Bogor. 
[IPGRI] The International Plant Genetic Resources Institute. 2000. Descriptors for Bambara Groundnut (Vigna subterranea). https://www.bioversityinternational. org/fileadmin/_migrated/uploads/tx_ news/Descriptors_for_Bambara_gro undnut_Vigna_subterranea_324.p df. [25 Februari 2018].

Kuswanto, Waluyo B, Pramantasari RA, Canda S. 2012. Koleksi dan evaluasi galur-galur lokal kacang bogor (Vigna subterranea). Seminar Nasional PERIPI (Perhimpunan ilmu pemuliaan Indonesia). 2012 Nov 67;Bogor, Indonesia. Bogor (ID) : Institut Pertanian Bogor. [diunduh pada 2018 Februari 24]. Tersedia pada

:http://kuswanto.lecture.ub.ac.id /files/2012/11/Kus-Peripi-2012.pdf.

Malau Sabam. 2005. Biometrika Genetika dalam Pemuliaan Tanaman. Medan:Universitas HKBP Nommensen.

Manggung RER, Qadir A, Ilyas S. 2016. Fenologi, morfologi dan hasil empat aksesi kacang bambara (Vigna subterranea (L.) Verdc.). J Agron Indo. 44(1):47-54.

Mazahib AM, Nuha MO, Salawa IS, Babiker EE. 2013. Some nutritional attributes of bambara groundnut as influenced by domestic processing. International Food Research Journal 20(3):1165-1171.

Ntundu WH, Shillah SA, Marandu WYF, Christiansen JL. 2006. Morphological diversity of bambara groundnut [Vigna subterranea (L.) Verdc.] landraces in Tanzania. Gen Res and Crop Evol. 53:367-378.
Redjeki ES. 2007. Pertumbuhan dan hasil tanaman kacang bogor (Vigna subterranea L. Verdc.) galur Gresik dan Bogor pada berbagai warna biji. Prosiding Seminar Hasil Percobaan yang Dibiayai oleh Hibah Kompetitif; 2017 Agustus 1-2; Bogor, Indonesia. Bogor (ID) : Departemen Agronomi dan Hortikultura Fakultas Pertanian IPB. hlm 114-118. [diunduh 2018 Februari 23]. Tersedia pada http://www.agrohort.ipb.ac.id/downl oads/Prosiding\%20Hibah\%20Isentif \%202007\%2(Purnabakti\%20Prof.\% 20Jajah\%20Koswara)/Redjeki.pdf.

Syukur M, Sujiprihati S, Yunianti R. 2012. Teknik Pemuliaan Tanaman. Jakarta (ID): Penebar Swadaya.

Wicaksana N, Hindun, Waluyo B, Rachmadi M, Kurniawan A, Kurniawan H. 2013. Karakterisasi morfo-agronomis kacang bambara (Vigna subterranea L. Verdc.) Asal Jawa Barat. Di dalam : Wicaksana N, Kurniawan A, Waluyo B, Kurniawan $\mathrm{H}$, editor. Peran Nyata Hortikultura, Agronomi dan Pemuliaan Terhadap Ketahanan Pangan. Seminar Nasional 3 in ONE Hortikultura, Agronomi dan Pemuliaan Tanaman; 2013 Agust 21; Malang, Indonesia. Malang (ID) : Fakultas Pertanian, Universitas Brawijaya. hlm 349-357.

Wulaningrum RA, Wisnu S, Mohammad A. 2013. Pengaruh asam organik dalam ekstraksi zat warna kulit buahal manggis (Garcinia mangostana). Indonesian Journal of Chemical Science. 2(2):119-124. 